\title{
19. Olfala Histri Wea i Stap Andanit long Graon. Archaeological Training Workshops in Vanuatu: A Profile, the Benefits, Spin-offs and Extraordinary Discoveries
}

\author{
Stuart Bedford, Matthew Spriggs, Ralph Regenvanu and \\ Salkon Yona
}

Archaeological research was included in the Vanuatu governmental moratorium on humanities-based research in Vanuatu from 1984 to 1994 (Bolton 1999: 1) and consequently it languished very much in a pioneering phase, reliant on interpretations from the results of a handful of influential projects that had been carried out through the 1960s and 70s. Right up to the mid-1990s fundamental questions relating to the initial colonisation and settlement of the archipelago and the succeeding cultural transformations which took place were still largely unanswered. Much of the country remained an archaeological terra incognita (Bedford et al. 1998; Bedford 2006a). However, the establishment of the Vanuatu Cultural and Historic Sites Survey (VCHSS) in 1990, a separate but associated entity to the Vanuatu Cultural Centre (VCC) and funded primarily by the European Union, was a major positive boost to archaeology. It started with a team of professional archaeologists, David Roe and Jean-Christophe Galipaud, and a less experienced but energetic group of ni-Vanuatu, some of whom would later go on to play influential roles in the long-term future of the VCC. The VCHSS initially comprised the manager Martha Yamsiu (later Kaltal) and field officers, Peter Kolmas, Ralph Regenvanu, Nicolas Vanusoksok, François Wadra and Fidel Yoringmal.

Its aims were to build and maintain a database of sites of cultural, archaeological and historic significance; to conduct surveys to identify and document these sites; train ni-Vanuatu staff in techniques of survey, research planning and execution; consider and establish procedures for determining, assessing and responding to threats to sites; encourage and develop the study of archaeology and history of Vanuatu and promote an awareness of its importance as part of the country's cultural heritage (Regenvanu et al. 1992; Roe and Galipaud 1994). The VCHSS organised and undertook site surveys in conjunction with the locallybased VCC filwokas and local communities. Focus was generally on the recording of historical and cultural/kastom sites, particularly in areas where development 
was being planned. Surveys were carried out on many islands in the archipelago. While archaeological research projects involving targeted excavations were not a component of the work of the VCHSS, its distinctly ni-Vanuatu approach, style and perspective that developed over a number of years (Regenvanu et al. 1992; Roe and Galipaud 1994; Roe et al. 1994), laid the foundations for collaborative archaeological research and training that was further developed following the lifting of the moratorium in 1994.

The VCHSS was incorporated administratively into the VCC in 1995 (Tryon 1999: 12-13), by which time staff included the late Jean-Paul Batick, Regina Batick and the late Willy Damelip. They were joined some time later by Marcellin Abong and Richard Shing, both of whom had completed some University training in archaeology. With the establishment of the VCC Research Policy and issuing of research permits in 1994 (Regenvanu 1999), research orientated archaeological projects were initiated. The first of these was the ANU-Vanuatu National Museum Archaeology Project which was started in 1994 on the island of Erromango by Matthew Spriggs, added Malakula Island and Bedford in 1995 and has continued in various guises until today (Bedford et al. 1998; Bedford and Spriggs 2008). A training component was first introduced in 1996 (Bedford et al. 1999; Spriggs 1996) based at the Mangaasi/Arapus site on the west coast of Efate.

\section{Mangaasi/Arapus archaeological training workshops 1996-2003}

The site of Mangaasi, on the west coast of Efate, was made famous throughout the archaeological world by the pioneering work of José Garanger who excavated a single area of 118 square metres there in 1967, uncovering both the remains of Chief Roi Mata's village near the surface of the site and evidence of much earlier occupation with thousands of pottery sherds at deeper levels (Garanger 1972). The site was dated at the time to 2700 BP (BP = 'Before Present', with 'Present' taken conventionally as 1950) and the distinctive pottery style found there and in other areas of Efate and the Shepherd Islands was named 'Mangaasi' in honour of the site. No further archaeological work took place at the site for another 30 years. Meanwhile a large number of other archaeological research projects had been carried out in different countries around the Pacific, and a huge amount of new information collected which was beginning to cast doubt on some of the conclusions of Garanger and other earlier researchers in Vanuatu. Pleistocene occupation had been identified in Island New Guinea and the Northern Solomons which opened up the same possibility for Vanuatu. Questions were also beginning to be asked about how the Mangaasi ceramic 
tradition fitted into the general picture. Claims that it was unrelated to Lapita and represented a separate cultural group contemporary with Lapita, were being seen as increasingly problematic (Spriggs 1984, 1997; Ward 1990).

In 1996 with these research questions in mind the Mangaasi site was added to the sites to be investigated under the umbrella of the ANU-Vanuatu National Museum Archaeology Project. It was decided that a significant training component should be added (Bedford et al. 1999). The necessary additional funding that facilitated the training component came from grants to the National Museum of Vanuatu, coordinated by Yosihiko Sinoto of the Bishop Museum in Honolulu, as part of the pilot archaeological training program of the Sasakawa Pacific Island Nations Fund (SPINF) for 1996-8 and from the Japanese Government via a grant to the Pacific Islands Development Program at the EastWest Center in Honolulu in 1999. In 1996 the South Pacific Cultures Fund of the Australian Federal Government also made a significant contribution. For Project reports during this period, see Regenvanu and Spriggs (1996), Spriggs (1996) and Spriggs and Bedford (1999).

The site was ideally located in terms of logistics not far from the VCC in Port Vila. More importantly there was widespread support from the local community, some of the more senior members of which had worked with Garanger decades before. In 1996 the emphasis was on the training of VCC and VCHSS staff and members of the local community, but as both funding and the numbers of experienced VCHSS staff increased over the next three years the workshops could accommodate larger numbers. These comprised primarily VCC filwokas from both Efate and other islands who, except for a very few, had no experience of archaeology. A range of skills were imparted to the participants, depending in part on their literacy and other educational skills and in part upon their previous archaeological experience. VCHSS staff took on increasing responsibility for training as their experience developed. From 1999, excavations at different parts of the site were directed by Richard Shing and Marcellin Abong, while site survey and mapping were overseen by Willy Damelip. The program was conducted largely through informal practical training sessions, with participants being introduced to all aspects of archaeological excavation and survey throughout the five-week workshops. The skills and understanding developed through the program included the following: the purpose and value of archaeological research; basic principles of archaeological excavation and recording techniques; basic principles of stratigraphy and the recognition of different layers; techniques of wet and dry sieving of excavated sediments; artefact recognition and sorting of screened sediments into artefact classes; artefact handling and specialised collection techniques for such things as in situ charcoal; how archaeologists construct a site picture from the remains found, and why they use particular excavation strategies; basic concepts related to archaeological constructions of Pacific colonisation and settlement. 
The training workshops proved to be very successful in terms of their primary objectives, and the research clarified the place of Mangaasi pottery in the local cultural sequence (Bedford 2000, 2006a). In addition, when in 1999 excavations were extended to Arapus, across the Mangaasi Creek which marked the southwest boundary of the site, they uncovered both earlier and much more extensive deposits than those identified at Mangaasi. These have ultimately been revealed to represent one of the best-preserved archaeological sites of its type in the Pacific (Bedford and Spriggs 2000; Spriggs and Bedford 2001). The famed Mangaasi site could now be seen as simply the periphery of a much larger site which had the potential to extend much further along the coast towards Mangaliliu Village. Funding was sought for a further three years from the Pacific Biological Foundation, and subsequently attracted further contributions from the New Zealand High Commission in Port Vila. Thus, with a break only in 2000, the training workshop on Efate continued from 2001 to 2003 (for project reports see Spriggs 2002, 2003, 2004a). For the first time there was participation by the women filwokas as well as the men. Excavations and training were focused the Arapus site but small teams extended the sphere of the workshop to Mangaliliu further southwest, where Richard Shing supervised investigations, and to the neighbouring small islands of Lelepa and Nguna (Bedford 2004; Valentin, Shing and Spriggs 2005). Direct VCC filwoka and local community involvement in the excavations again proved to be the most effective method of raising awareness and the understanding of archaeological sites and what they represented as the project's area of operation was extended.

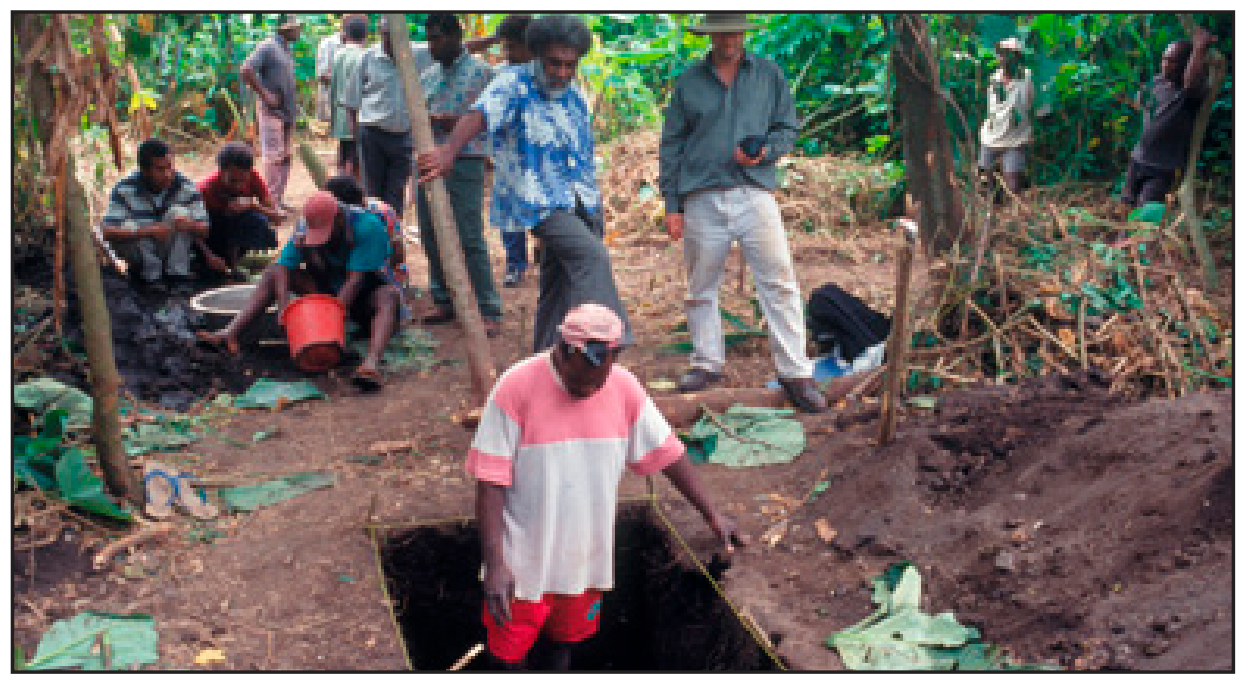

Figure 19.1. Excavation, sieving and sorting, Arapus site, West Efate 2001. Minister of Education Joe Natuman (centre) visits the site

(Stuart Bedford, photographer) 


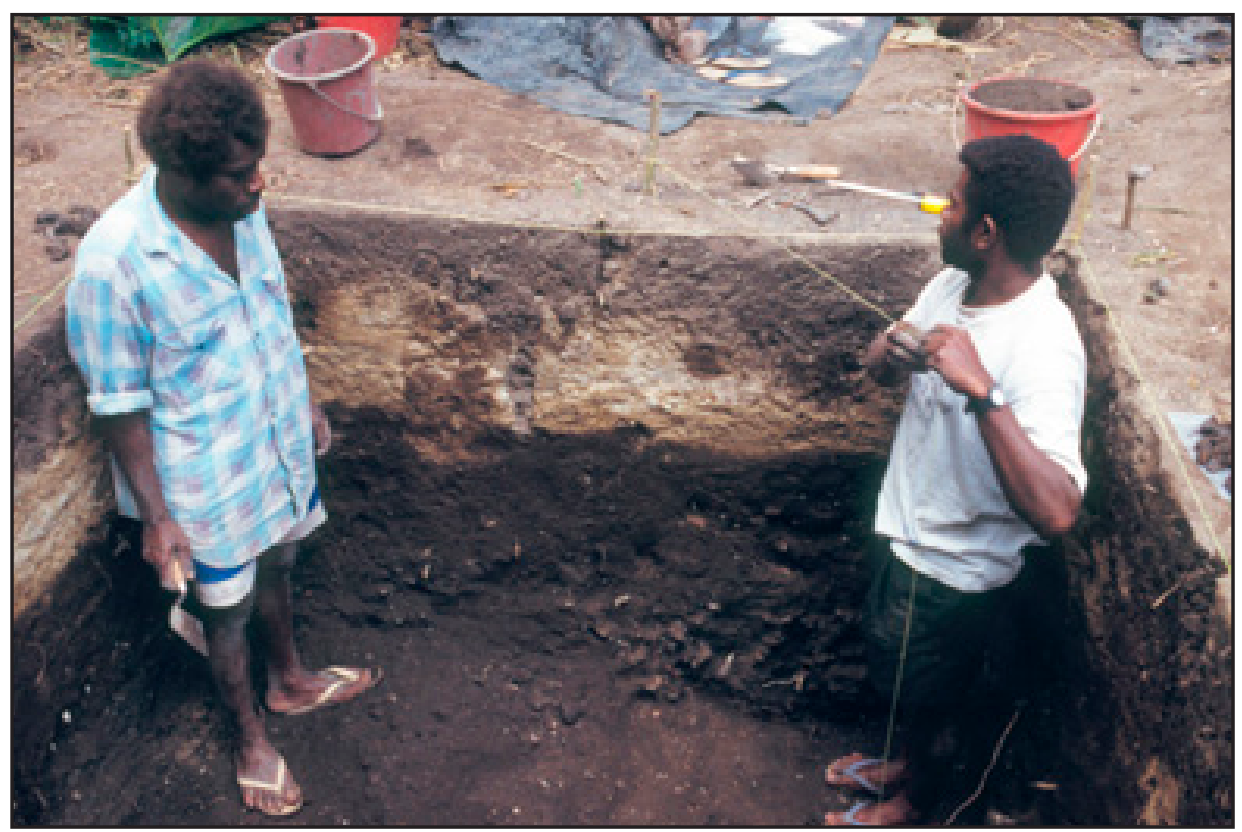

Figure 19.2. Excavators Joel lau (filwoka south Tanna) and Douglas Kalotiti (filwoka west Efate) recording excavated depth, Arapus site, West Efate 2001

(Stuart Bedford, photographer)

\section{Malakula archaeological training workshops 2001-2004}

In 2001 a further archaeological training workshop was started on the island of Malakula. It was the Vanuatu component of a project funded by the Sasakawa Pacific Islands Nations Fund (SPINF) entitled Distance Education in the SouthWest Pacific: Cultural Heritage Training 2001-2003. The program was jointly run by Glenn Summerhayes and Matthew Leavesley (Papua New Guinea component), Bedford (Vanuatu), the VCC and the Papua New Guinea Museum (Bedford and Leavesley 2004; Leavesley et al. 2005). The broad objectives of the Vanuatu component of the program were to train ni-Vanuatu in the following areas of cultural heritage management:

- identifying and recording cultural sites of significance;

- cultural and archaeological survey techniques;

- archaeological excavation methods;

- raising community awareness through liaison, education and dissemination of information. 
The Malakula archaeological training workshops were a natural development from those that had been carried out on Efate. They were specifically located on one of the northern islands of Vanuatu as they are more under-resourced in terms of trained personnel and previous educational programmes. The increasing threat from proposed mining activities and other development projects on these islands made the need for training and survey particularly urgent as little of the cultural heritage of these islands has been recorded. The training workshops were also designed to further develop and enhance: 1. the established structure of site survey and 2. the recording processes that were employed by the VCHSS. VCC filwokas from islands who had not previously participated in earlier training on Efate were particularly encouraged to join the new programme. The small islands of northeast Malakula and the Maskelyne Islands of the southeast were selected for the workshops (Bedford and Regenvanu 2002, 2003).

Heightening of community awareness was a major objective of the Malakula workshops and it was felt that this could be most effectively achieved by running the workshops in a number of different areas. This posed a number of logistical challenges, with a core group of around 15 people being together for five weeks and shifting between different islands and communities where archaeology was virtually unknown. Crucial to the success of the workshops was Numa Fred Longga, curator of the Malakula Cultural Centre (MCC) who had participated in excavations at Mangaasi/Arapus in 1999 and the by-then fully experienced staff of the VCHSS. The workshop started on Uripiv Island, the home island of Numa Fred, where both his standing as curator of the MCC and his ability to explain in local language the objectives of the workshop proved a major benefit. VCC filwokas mostly from northern Vanuatu made up the majority of the trainees, including filwokas from other small islands of Malakula where the workshop was to be shifted to following Uripiv. Fidel Yoringmal, long-retired from the VCHSS, joined the workshop on his home island of Wala and was again able to explain in detail in local language the objectives of the workshop. A similar scenario eventuated on Vao Island with the participation of Vianney Atpatoun, ex-curator of both the VCC and MCC, who had some experience of archaeological investigations including touring Lapita sites in New Caledonia.

There were two main aspects to the training workshops on Malakula. One was focused on archaeological investigation and survey in an attempt to build up a picture of the long-term history of the islands. The other was surveying the islands for ceremonial structures and old villages which were then recorded in detail. Traditional stories relating to these structures or sites were also recorded. The archaeology of the small islands of Malakula had up until that time been barely touched, so it was with some relief that after only four days on Uripiv Island we were able to identify well-preserved deeply-stratified deposits including evidence of Lapita, the foundation culture for Vanuatu about 3000 
years ago (Bedford 2003). This ensured the success of both the archaeological aspect of the training workshop but also greatly facilitated community interest and awareness. Ultimately, archaeological workshops were held on seven small islands of Malakula (Uripiv, Uri, Wala, Atchin, Vao [NE Malakula] and Uliveo and Sakao [Maskelynes]). Following the identification of particularly well-preserved Lapita deposits on Vao in 2003, funding was sought for further excavations. An additional, more research-orientated workshop was held on Vao in 2004 with the increasingly experienced Malakula filwokas making up the greater part of the excavation team (Bedford 2005).

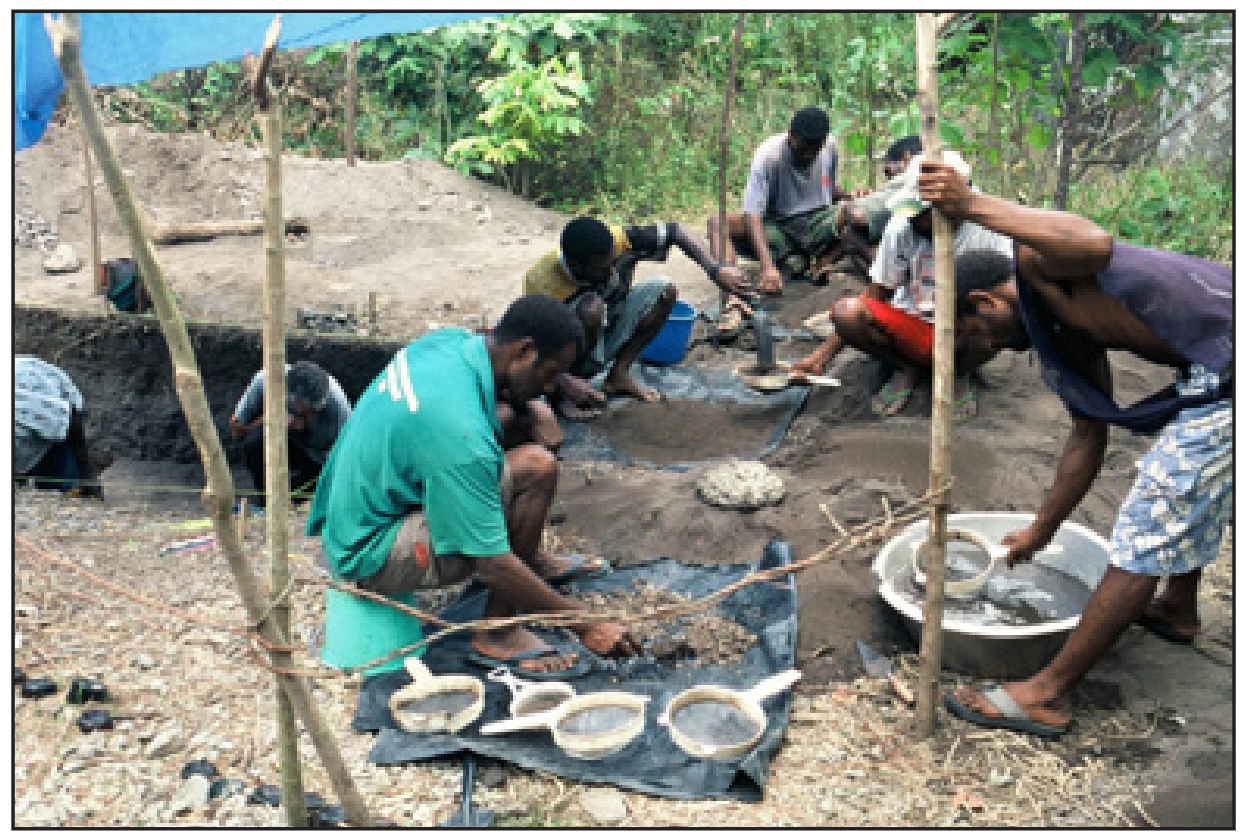

Figure 19.3. Excavation, sieving and sorting, Vao Island 2003

(Stuart Bedford, photographer)

\section{Benefits and spinoffs}

Direct participation and collaboration of VCC and VCHSS staff, filwokas and local communities in actual excavations carried out during the training workshops were fundamental in facilitating a basic understanding of archaeology and its wider relevance and importance. The archaeology in those areas where the workshops were held was also particularly amenable for such awareness programs. The deeply-stratified well-preserved sites regularly revealed features through the different layers such as hearths, various items of material culture and midden debris, with which people were generally familiar. Certainly when 
some of these features or midden debris were being recovered from depths of more than two metres below the ground surface a sense of the development of stratified deposits over time or the idea that graon $i$ stap gro could be more easily appreciated.

The workshops proved also to be fertile venues for exchange of information between trainers and trainees. Roles could often be reversed when particular artefact forms from more recent deposits were recognised by filwokas or local villagers. Environmental and cultural information in relation to faunal remains and particularly shellfish could also be readily accessed. When a 'shellfish workshop' was established on Uripiv in 2002 to identify the large numbers of shellfish being recovered from the site there, it provided an ideal platform for discussions ranging from size variation and variety of species over time, through the identification of species no longer found in the area, to the traditional usage of various species. Extinct species have also been identified in the course of the excavations, such as the extinct land crocodile found at Arapus (Mead et al. 2002), as well as several extinct or locally extirpated bird species. These discoveries have helped raised environmental issues and awareness in communities.

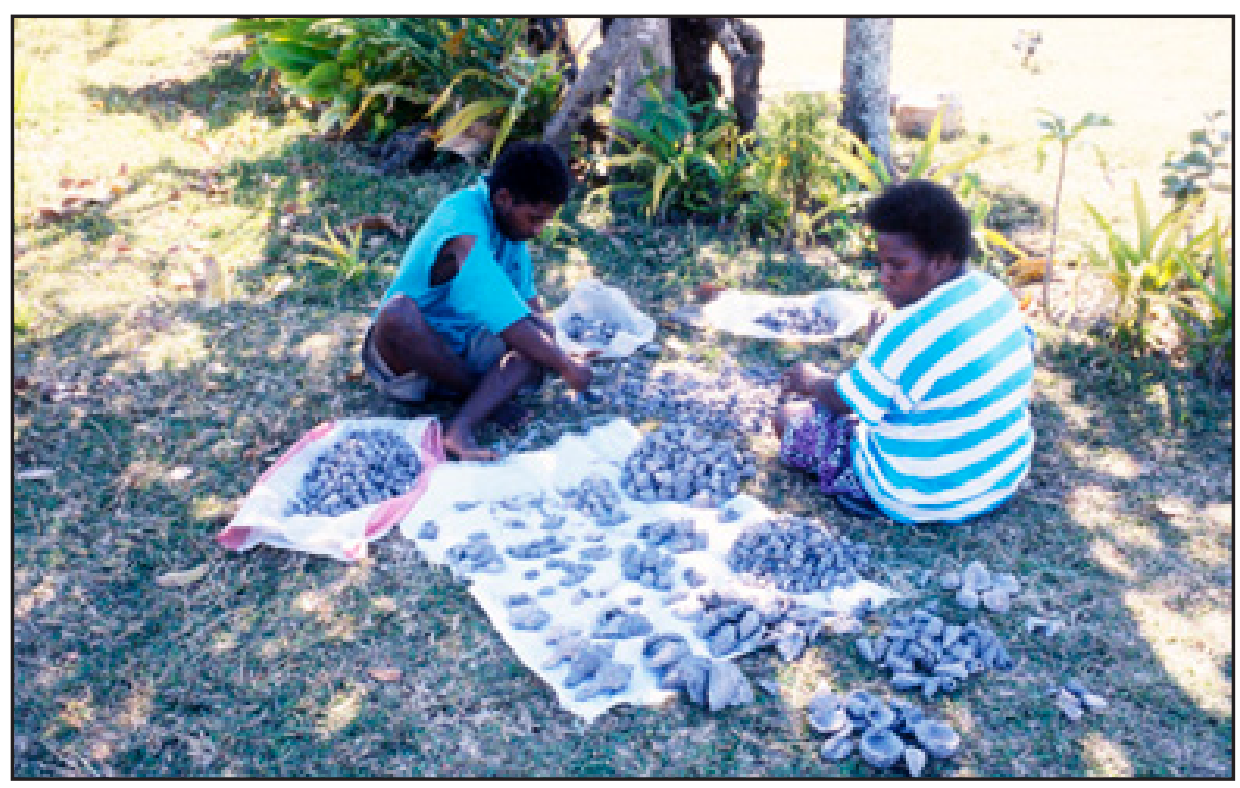

Figure 19.4. Shell analysis workshop, Uripiv Island, Malakula 2002

(Stuart Bedford, photographer)

Communities benefitted greatly from the workshops being held in their immediate area, not least financially. Accommodation in the villages was paid for, local labour was hired to participate, most food was sourced locally and its 
preparation involved the paid participation of local women's organisations. For small communities with limited opportunities to participate in the monetary economy, the projects' financial inputs were significant. The participation over many years of most of the men and a smaller number of the women VCC filwokas greatly facilitated the much wider dissemination of archaeological information and awareness. Filwokas play a crucial liaison role between foreign researchers and local communities, and in this regard are able to explain what archaeological work entails and its aims and values. After participating in the workshops, all trainees became fully conversant with the processes involved in archaeological work and were able to explain them to their home communities, who sometimes confuse archaeology with mineral exploration activities. Filwokas also provide an archipelago-wide network of VCC representatives who, having now participated in the archaeology training workshops, have been able to relay information to the VCHSS on the appearance of archaeological remains uncovered during local village activities or larger development projects.

Following now some eleven workshops, various staff of the VCHSS have accumulated substantial experience and understanding of archaeological method and theory and would be capable of running such workshops independently. The research aspect of the workshops has also aided the work of the VCHSS in other ways. A detailed cultural sequence for Central Vanuatu has now been established beginning with Lapita to Erueti to Mangaasi and beyond (Bedford 2006a). The outline of a similar cultural sequence is also available for Malakula (Bedford 2001). This now means that sites found during surveys can be dated and their historical significance assessed without incurring significant extra costs such as radiocarbon dating.

Local and wider community awareness was further raised through regular oral presentations to local communities, landowners, the Friends of the Vanuatu National Museum group and school and university students who toured the sites in large numbers. Educational groups ranged from pre-schoolers to students from teacher training institutions and the University of the South Pacific, Emalus Campus in Port Vila. Other visitors included Government MPs, Provincial government officials, and representatives from Diplomatic missions. Visits from schools provided a rare opportunity for the students to see first hand, and in some cases participate in, the excavations. An added bonus of the school visits is the fact that most high schools in Vanuatu comprise students from all over the country, which further contributes in the dissemination of interest and information to a wider audience. Martha Yamsiu-Kaltal and Richard Shing particularly have taken the principal lead in community and visiting group presentations. The response from all educational institutions was extremely positive, but teachers and students alike lamented the fact that they did not have ready access to information on the archaeological history of Vanuatu or the Pacific generally. 


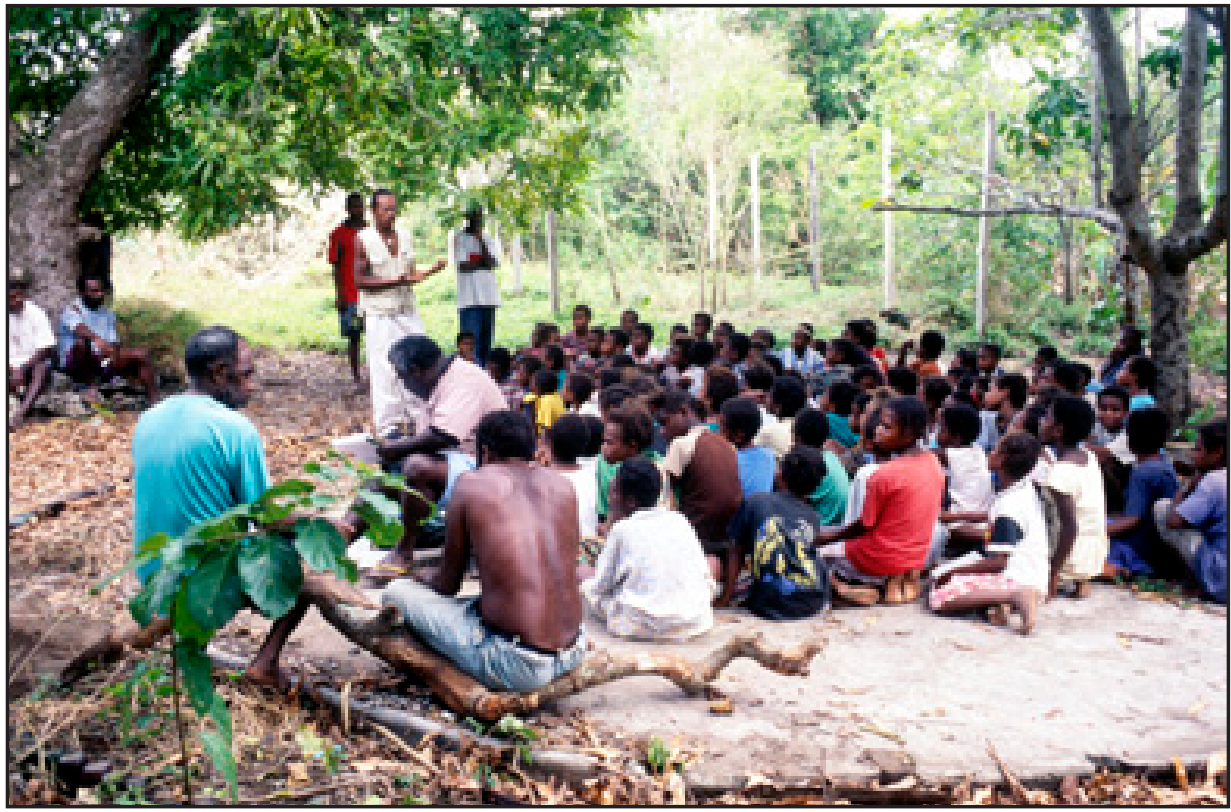

Figure 19.5. Richard Shing leads a public presentation on Vao Island 2003

(Stuart Bedford, photographer)

In a major effort to address this very issue the VCC initiated the National History Curriculum Project in 2003 that produced the three-volume publication Histri Blong Yumi Long Vanuatu (Lightner and Naupa 2005), aimed at ultimately providing a basis for a core curriculum high school subject on the history of Vanuatu. A French translation of the first two of these volumes appeared in 2010. Archaeological information, much of which was generated during the training workshops, makes up a substantial component of Volume One. At a less academic and less ambitious level, but one that serves well the needs of grassroots ni-Vanuatu in terms of providing basic archaeological information, was the production of a cartoon format booklet Wokbaot Bakagen wetem Olgeta Blong VCHSS. Saet Sevei mo Akaeoloji (Kaltal, Nojima and Bedford 2004). Developed during the Malakula workshops it is essentially an update, with the addition of archaeology, of the original VCHSS cartoon publication which introduced and highlighted the role of the VCHSS site surveys in the early 1990s (Regenvanu et al. 1992). In line with obligations outlined under the VCC research policy, annual reports on the workshops and their results were produced in both Bislama and English for distribution to local communities and deposition in the Vanuatu National Library.

The increasing accessibility and use of the World Wide Web has also been taken advantage of with many of the reports and latest results able to be viewed on the VCC web site (www.vanuatuculture.org). During the Mangaasi workshop 
in 1998 a pioneering web-based interactive learning site was established where field data and photographs from the excavations were posted on a daily basis, inviting feedback and discussion from a world-wide audience. This was the first time anywhere in the world that a 'live' archaeological excavation was presented on a day-by-day basis on a dedicated web site (Spriggs 1999, 2000). The innovative project design led to Spriggs being awarded a prize-grant to undertake the web project from the Kon-Tiki Museum - Telenor 'No Barriers' Fund of Norway. Additional equipment support came from the Apple University Development Fund in Australia, and a satellite phone base was temporarily established at Mangaliliu Village during the course of the project to put material up on the web. For a brief moment at least, Vanuatu led the world in this sort of web-based learning.

A series of academic papers have also been generated from the archaeological results of the workshops (Bedford 2000, 2003, 2006a, 2006b; Bedford and Spriggs 2002; Bedford et al. 1998; Horrocks and Bedford 2005; Spriggs and Bedford 2001) which in the case of the Mangaasi/Arapus excavations have made a valuable contribution to the nomination of the Chief Roi Mata's Domain as a UNESCO World Heritage Site (Spriggs 2006). Another spin-off was that the same excavations were used as the basis of an artistic reconstruction of this colonising period which was ultimately used on the Vanuatu Lapita stamps issued by the Post Office in 2005 (Figure 19.6).

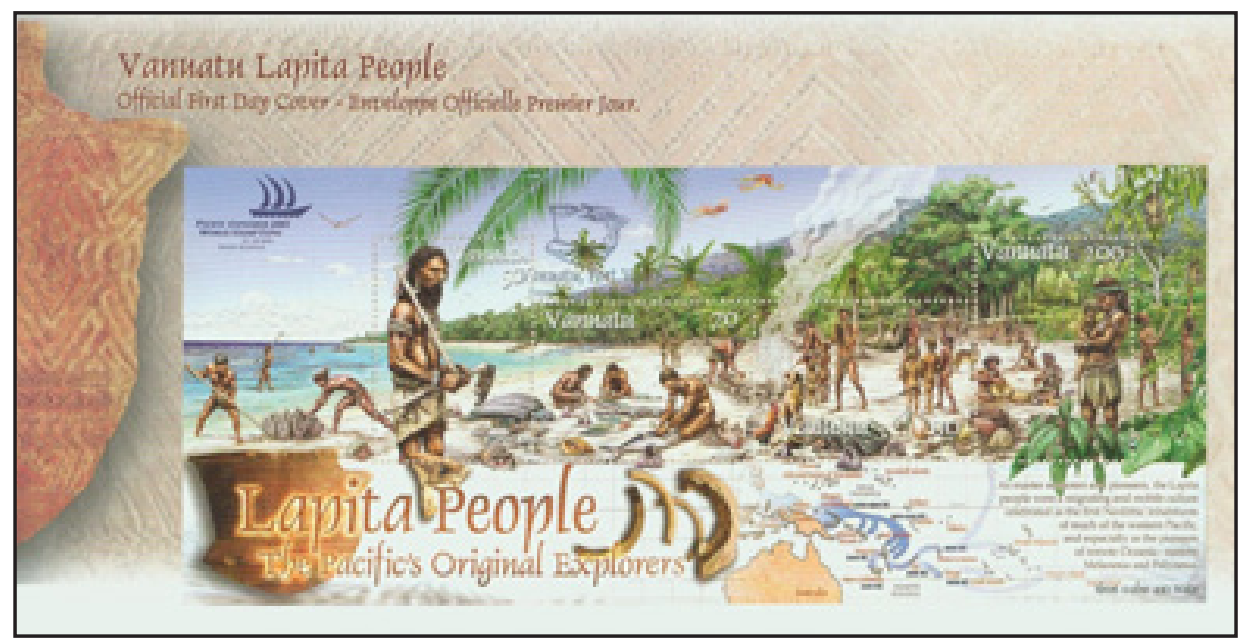

Figure 19.6. Vanuatu Lapita stamp issued in 2005

(copyright Vanuatu Post)

Radio interviews have been broadcast nationally on a regular basis discussing the aims and results of the workshops. As radio is the only form of communication to which the whole of the country has access, regular features on Radio Vanuatu 
were seen as essential. Much of their success can be attributed to Abong Thompson, former Vanuatu National Radio presenter now at the VCC, who recorded the interviews and compiled the shows that were most often broadcast on Saturday nights on the VCC Kastom mo Kalja half hour. Feature articles have appeared on a regular basis in Vanuatu newspapers and coverage has also been extended to TV Vanuatu. The Vanuatu National Film and Sound Unit of the VCC has filmed many of the excavations over the years and produced a number of films. They include Footprint blong Bubu (Pathways of the Ancestors) and Yumi tokbaot Roy Mata (Stories about Roy Mata), the second of which was developed directly out of the excavations at Mangaasi/Arapus and was the first-ever documentary made explicitly for the new TV Vanuatu channel. Both of these films were shown to local community and school groups on Malakula during the workshops there as their content had a direct relation to the archaeological methods used and the materials that were being uncovered on those islands.

\section{Extraordinary discoveries}

Prior to attendance at the various archaeological training workshops most VCC filwokas had little idea that the sherds of pottery they regularly came across in their gardens had anything to do with the cultural heritage. In a number of cases they were seen as having biblical connections (Bedford 2006a). This was certainly Salkon Yona's experience prior to his attendance at the Mangaasi/ Arapus workshop of 2003.

Bifo mifala long Epi oli bin lukim plante pis sospen graon long ol garen blong mifala. Mi bin askem ol olfala papa mo mama blong mifala wanem samting ia? I gat tufala storian blong hem. Wan i talem se olgeta oli ol pispis blong ten komanmen wea Moses $i$ bin sakem mo $i$ brokbrok $i$ go olbaot. Wan narafala storian i talem se olgeta oli ol pis blong wan bigfala wotatank blong god spirit long Emae wea afta wan bigfala ren i bin filimap tumas i folfoldaon mo i go olbaot (Yona 2006). ${ }^{1}$

It was a revelation to hear that through archaeological research it had been established that, as on Efate and clearly in evidence in the midden deposits he was excavating, communities on all islands of Vanuatu had once produced pottery, dating as far back as 3000 years. Yona's enthusiasm for the workshop was regularly shared with fellow Epi islanders resident in Vila.

1 On Epi we find a lot of pieces of pottery in our gardens. I have asked the older people in the community what they were. There are two stories associated with it. One is that they are pieces of the Ten Commandments which having been discarded by Moses broke into thousands of pieces and were spread around. Another is that they were once part of a large water-tank owned by the spirits of Emae which burst into many pieces following heavy rain. 
Mi bin storian long woksop plante wetem ol fren blong mi wea oli stap long Vila. Wan blong olgeta [Charlie Nati] i bin talem se hem tu i bin lukim fulap samting olsem sospen graon long Teouma wea hemi draevem buldos blong makem ples blong fidim naora. Mi bin askem hem blong karem wan pis i kam olsem mi save lukluk gud long hem. Taem mi lukim bigfala pis sospen wea man ia $i$ bin karem $i$ kam mi tingse hemi mas Lapita from $i$ gat wan difren disaen olgeta. Mi bin karem pis ia long Kaljoral Senta blong soem long olgeta (Yona 2006). ${ }^{2}$

Yona's identification of the sherd ultimately led to the discovery of one of the more important archaeological sites yet found in the Pacific, the Lapita cemetery of Teouma (Bedford et al. 2004, 2006).

The Australian National University-Vanuatu National Museum led excavations took place initially at Teouma over three seasons (2004-2006) (Shing et al. 2005, 2007a) with support from (among others) the National Geographic Society (Spriggs 2007) and the Pacific Biological Foundation (Spriggs 2004b). Subsequently, between 2008 and 2010, further excavations have been carried out with funding from the Australian Research Council (Bedford et al. 2010). The excavations have generated unprecedented interest both locally and worldwide. The spectacular remains uncovered at the site and its accessibility facilitated a major public awareness campaign. School visits and guided tours for the general public and government and diplomatic officials were particularly promoted and even included a visit by the President and the First Lady and party in 2005. Display boards were set up at the excavations, and a pamphlet (Shing and Bedford 2005 [updated in 2007 (Shing et al. 2007b)]) and poster about archaeology and the excavation were provided on site and have subsequently been distributed to schools and communities throughout the country. The pamphlet and poster were funded by the Snowy Mountains Electricity Commission (SMEC) Foundation. Excavation participation by school students was encouraged and facilitated through the screening of deposits to retrieve artefacts in an area of the site that had been disturbed by quarrying. In 2004 alone, more than 1000 schoolchildren visited the site. The excavations received regular high profile coverage in Vanuatu and international newspapers, radio and television, as well as several overseas documentary filmmakers, and were the focus of the Friends of the Vanuatu National Museum calendar for 2006.

Although the Teouma excavations were conceived within a 'rescue' framework, to establish how much damage had been done by quarrying activities and how

2 I talked on a regular basis with friends in Vila about the workshop. One of them [Charlie Nati] said that he had seen pieces of pottery at Teouma where he was driving a bulldozer on the prawn farm construction site. I asked him to pick up a piece next time so that I could have a good look at it. When I saw the sherd that he had brought from the site I thought that it looked like Lapita as it had a very distinctive design. I took it to the Cultural Centre to show it to people there. 
much of the site remained intact, it did provide some further opportunities for training. In 2005 community representatives from Eton village in South Efate participated in the excavation. In 2006 the funding from the National Geographic Society facilitated the participation of five students-Solomon Islanders and ni-Vanuatu-from the University of the South Pacific main campus in Suva, Fiji and a further USP participant from Vila (Spriggs 2007). There were also opportunities in all years at Teouma for volunteer participation by Vanuatu-based and international participants from Australia, France, New Caledonia and New Zealand, as well as the professional collaboration of French, New Caledonian and New Zealand researchers.

A major Lapita exhibition was opened at the National Museum in 2006 following the return of four reconstructed Lapita pots from the Australian Museum in Sydney that had been recovered at Teouma in 2004 and 2005. The homecoming of these pots was an event to celebrate, particularly so for VCC curator Takaronga Kuautonga who had spent two months in Sydney collaborating in their reconstruction, funded by ICOM (International Council of Museums) Australia. With a further two complete vessels having been recovered from the site in 2006, Vanuatu can now boast of having 70 per cent of the world's collection of whole early Lapita vessels. The pots were transported to the Musée de Quai Branly in Paris for exhibition for two months from November 2010, along with other complete pots from New Caledonia. This Lapita exhibition represents the first ever exhibition dedicated to Pacific archaeological material to be held outside the Pacific and Australasian region. A 350-page bi-lingual catalogue was published in Paris for the exhibition (Sand and Bedford (eds) 2010), and at the same time, a tri-lingual companion booklet was produced by the Vanuatu Cultural Centre (Bedford, Sand and Shing 2010).

The second tranche of excavations, starting in 2008, led to an application for AUSAID funding to further develop School participation. Funding was obtained, and a very successful program of school visits and participation in excavation of the site took place in 2008 and 2009, with tours in English and French led by Richard Shing and by Jean René of the Alliance Française in Port Vila. Feedback reports were given to individual schools discussing the objects that their students had found during their work at the site. New booklets and posters in English, French and Bislama were produced and distributed to the students and teachers as part of this program. Although funding had run out by 2010 , a less-ambitious program of school participation continued during that year. 


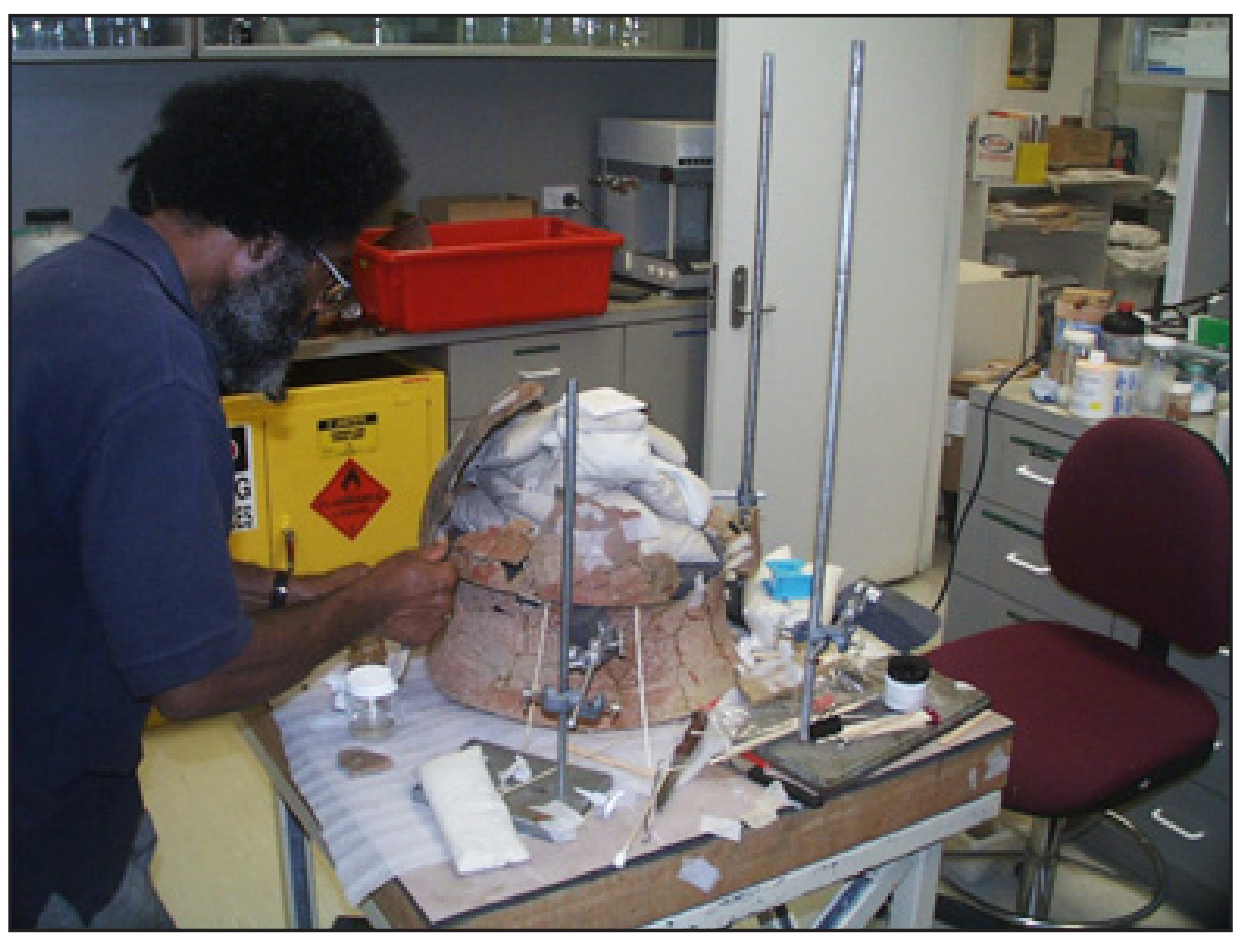

Figure 19.7. Takaronga Kuautonga at the Australian Museum restoring the Lapita pots

(courtesy of the Australian Museum)

There have also been additional reports more recently from filwokas of archaeological deposits turning up in different parts of Vanuatu. Filwoka Paul Vuhu, who attended the 1999 workshop on Efate, reported large sherds of pottery being eroded by the sea on the east coast of Ambae. A subsequent visit to the island confirmed a series of cultural deposits buried by volcanic ash. Excavations took place in 2007, and a report on them is in preparation. They revealed evidence of catastrophic volcanism that had buried sites over a wide area about 900 years ago; there are implications here for current volcanic hazards research. On Erromango ex-VCC filwoka Sempet Naritantop reported deeply buried cultural deposits with pottery at two sites adjacent to the Williams River in Dillons Bay, making a special trip to Port Vila to brief VCC staff in 2007. These are very significant discoveries; pottery is extremely difficult to find on Erromango as people gave up using it there around 2000 years ago (Bedford 2006a). An ANU team working with the Dillon's Bay community and Erromango filwoka Jerry Taki, conducted excavations at these sites in the second half of 2010, again providing an opportunity for community awareness activities. A major site probably going back about 2700 years appears to extend under much of the village at Dillon's Bay. 


\section{Conclusion}

The archaeological training workshops have been collaborative projects that evolved and improved through experience, have achieved their objectives and, through a momentum of their own, have realised much more. The outcomes are witnessed by the broadened skills-base and understanding of VCC, VCHSS staff and filwokas and by the greatly-increased information about Vanuatu's rich cultural heritage which has been disseminated through TV, radio, newspapers, web sites, educational manuals, pamphlets, comic books and exhibits in the National Museum. A wide range of the ni-Vanuatu public has been exposed to archaeology and cultural heritage issues through these media.

The deeply-stratified and well-preserved archaeological deposits at the sites chosen for the workshops have highlighted the fact that Vanuatu has some of the best preserved archaeological sites in the Pacific. There is now worldwide recognition of the significance of the archaeological heritage found in Vanuatu, confirmed in 2009 by the success of the nomination of the Chief Roi Mata's Domain in northwest Efate to the World Heritage List. This formed, along with the Kuk Swamp Early Agricultural Site in Papua New Guinea, the first successful World Heritage cultural nomination by independent Pacific Island countries. The major Lapita exhibition in Paris in 2010-11 is further evidence of such international recognition.

What has been absolutely crucial to the success of the workshops and excavations has been the opportunity to tap into the resources of a well-respected and wellrun national cultural institution such as the VCC. Without its collaboration the workshops would not have taken place. The VCC filwoka system, which operates across the islands, facilitated the wide dissemination of information. Vanuatu can now arguably claim to have one of the best educated populations at a grassroots level in relation to archaeology anywhere in the Pacific. With the inclusion of information about the archaeology of Vanuatu in the High School history curriculum its acceptance and importance can only be further enhanced.

An obvious and immediate major benefit, certainly in archaeological terms and highlighted by Yona's discovery, is the reporting archipelago-wide of archaeological deposits or materials being uncovered by knowledgeable and informed ni-Vanuatu. A more long-term benefit is archaeology's contribution to a developing sense of identity for the population of what is still comparatively the young nation of Vanuatu. The notion of a taem blong daknes (time of darkness) referring to Vanuatu before the arrival of Christianity was hammered into the national psyche by missionaries during the nineteenth and twentieth centuries. It is one that still pervades much Vanuatu thinking today (Regenvanu 2005:39). Archaeological evidence is being used to present a more balanced perspective 
on the nation's past. To find out that your ancestors were the first explorers and colonisers of all the islands of Eastern Melanesia and Western Polynesia more than 1000 years before the birth of Christ, and participated in the greatest maritime colonisation episode in world history, can have a salutary effect in helping to achieve a more balanced historical perspective.

In 1996 the then Minister of Culture Joe Natuman in his opening address to the Lapita Archaeology Conference held in Port Vila stated that 'We in Vanuatu will need to do more work in establishing firmly our early history because it is important for our identity as a people, as a country, and as a nation in the region and the world at large' (in Galipaud and Lilley 1999: 15). While the Minister's sentiments will always hold true as far as the need for more work to be done is concerned, revealing the early history of Vanuatu through projects such as the archaeological training workshops has without question made substantial advances over the years since the lifting of the research moratorium. Equally important has been the dissemination of information gleaned from those workshops and other research projects through such networks as the VCC filwoka system. Together they have substantially raised the profile of the nation's approximately 125-generation history in ni-Vanuatu consciousness.

\section{Acknowledgments}

As noted in the text, funding for the workshops at Mangaasi/Arapus came from the Australian Federal Government's South Pacific Cultures Fund (1996), the Sasakawa Foundation (1996-1998) and the Japanese Government through the Pacific Islands Development Program in Honolulu (1999), the Pacific Biological Foundation (2001-2003) and the New Zealand High Commission (2002-2003). For the workshops on Malakula funding came from the Sasakawa Pacific Island Nations Fund (2001-2003) and the National Geographic Society (2004). Funding for the Teouma 2004-2006 project as a whole was provided by the Pacific Biological Foundation, the National Geographic Society, the Australian Research Council, the Snowy Mountains Electricity Commission Foundation, ICOM Australia and Mr Brian Powell. The 2008-10 Teouma excavations were funded by the Australian Research Council, with the Schools program funded by AUSAID during the same period. In addition, critical financial and logistical support has been provided throughout the period 1994 to the present by the Department of Archaeology and Natural History and School of Archaeology and Anthropology at the Australian National University.

The smooth running of the workshops would not have been possible without the full support and participation of staff at the Vanuatu Cultural Centre, and particularly so the staff of the VCHSS and VCC accountant Jennifer Toa. The 
filwokas from the various islands were enthusiastic and attentive for the full period of the workshops and often provided training to the trainers. The VCC filwoka for West Efate Douglas Kalotiti was crucial to the success of all the work at the Mangaasi and Arapus sites, as was Numa Fred Longga, Curator of the Malakula Cultural Centre for the workshops on Malakula. Filwoka for South Efate Silas Alben has fulfilled a similarly critical role at the Teouma site during 2004-10. Although they are too many to list here individually, a special thank you goes to all Chiefs, landowners and local members of the fieldwork crews for their co-operation, assistance and friendship-literally hundreds of people have been involved in one way or another. Many thanks are also due to the local communities who supported the workshops with their hospitality and assistance.

\section{References}

Bedford, Stuart, 2000. Results from excavations at the Mangaasi type site: a re-assessment of the ceramic sequence and its implications for Melanesian prehistory. Bulletin of the Indo-Pacific Prehistory Association 19: 159-66.

Bedford, Stuart, 2001. Ceramics from Malekula, northern Vanuatu: the two ends of a potential 3000-year sequence. In The Archaeology of Lapita Dispersal in Oceania: Papers from the Fourth Lapita Conference, June 2000, Canberra, Australia, ed. G.R. Clark, A.J. Anderson and T. Vunidilo, 105-14. Canberra: Pandanus Books. Terra Australis, 17.

Bedford, Stuart, 2003. The timing and nature of Lapita colonisation in Vanuatu: the haze begins to clear. In Pacific Archaeology: Assessments and Prospects, ed. C. Sand, 15: 147-58. Nouméa: Les Cahiers de l'archéologie en NouvelleCalédonie.

Bedford, Stuart, 2004. Ripot i go long ol man Nguna long saed blong stadi blong Stuart Bedford mo Taman Willie long Arkeoloji blong Nguna, Julae 14 Kasem 18 2003. Report to Vanuatu Cultural Centre and Nguna community. Typescript, on file Vanuatu National Library.

Bedford, Stuart, 2005. The timing and nature of human colonisation of Vanuatu. Report to National Geographic Committee for Research and Exploration (Grant 7738-04). Typescript, on file Vanuatu National Library.

Bedford, Stuart, 2006a. Pieces of the Vanuatu Puzzle: Archaeology of the North, South and Centre. Canberra: Pandanus Press, Australian National University. Terra Australis 23. 
19. Olfala Histri Wea i Stap Andanit long Graon Archaeological Training Workshops in Vanuatu

Bedford, Stuart, 2006b. The Pacific's earliest painted pottery: an added layer of intrigue to the Lapita debate and beyond. Antiquity 80: 544-57.

Bedford, Stuart and Matthew Leavesley, 2004. Distance education in the SouthWest Pacific: culture heritage training 2001-2003. Report presented to the Sasakawa Pacific Island Nations Fund, Tokyo. Typescript, on file Vanuatu National Library.

Bedford, Stuart and Ralph Regenvanu, 2002. Summary report to the Vanuatu Government on distance education in the South-West Pacific: cultural heritage training 2001-2003. Workshop and Training Program on Uripiv and Wala Islands, Malakula 2001. Typescript, on file Vanuatu National Library.

Bedford, Stuart and Ralph Regenvanu, 2003. Summary report to the Vanuatu Government on distance education in the South-West Pacific: cultural heritage training 2001-2003. Workshop and Training Program on Uripiv, Uri, Atchin and Vao Islands, Malakula 2002. Typescript, on file Vanuatu National Library.

Bedford, Stuart, Christophe Sand and R. Shing, 2010. Lapita Peoples/Peuples/ Pipol. In Oceanic Ancestors/Ancêtres océaniens/Bubu blong ol man long Pasifik. Port Vila: Vanuatu Cultural Centre.

Bedford, Stuart and Matthew Spriggs, 2000. Crossing the Pwanmwou: preliminary report on recent excavations adjacent to and south west of Mangaasi, Efate, Vanuatu. Archaeology in Oceania 35: 120-6.

Bedford, Stuart and Matthew Spriggs, 2002. Of shell, stone and bone. a review of non-ceramic artefacts recovered from the first 1000 years of Vanuatu's archaeological record. In Fifty Years in the Field. Essays in Honour and Celebration of Richard Shutler Jr's Archaeological Career, ed. Stuart Bedford, Christophe Sand and D. Burley, 135-52. Auckland: New Zealand Archaeological Association Monograph 25.

Bedford, Stuart and Matthew Spriggs, 2008. Northern Vanuatu as a Pacific crossroads: the archaeology of discovery, interaction and the emergence of the 'ethnographic present'. Asian Perspectives 47(1): 95-120.

Bedford, Stuart, Matthew Spriggs, Hallie Buckley, Frédérique Valentin, Ralph Regenvanu and M. Abong, 2010. Un cimetière de premier peuplement: le site de Teouma, sud d'Efate, Vanuatu/A cemetery of first settlement: Teouma, South Efate, Vanuatu. In Lapita: Ancêtres océaniens/Oceanic Ancestors, ed. Christophe Sand, and Stuart Bedford, pp. 140-61. Paris: Musée du quai Branly/Somogy. 
Working Together in Vanuatu

Bedford, Stuart, Matthew Spriggs and Ralph Regenvanu, 1999. The Australian National University-Vanuatu Cultural Centre Archaeology Project 1994-7: aims and results. Oceania 70(1): 16-24.

Bedford, Stuart, Matthew Spriggs and Ralph Regenvanu, 2006. The Teouma Lapita site and the early human settlement of the Pacific Islands. Antiquity 80: 812-28.

Bedford, Stuart, Matthew Spriggs, Meredith Wilson and Ralph Regenvanu, 1998. The Australian National University-National Museum of Vanuatu Archaeological Project 1994-7: a preliminary report on the establishment of cultural sequences and rock art research. Asian Perspectives 37(2): 165-93.

Bedford, Stuart, Andrew Hoffman, Martha Kaltal, Ralph Regenvanu and Richard Shing, 2004. Dentate-stamped Lapita reappears on Efate, Central Vanuatu: a four decade-long drought is broken. Archaeology in New Zealand 47:39-49.

Bolton, Lissant 1999, Introduction. Oceania 70: 1-8.

Galipaud, Jean-Christophe and Ian Lilley (eds), 1999. The Western Pacific from 5000 to 2000 BP. Colonisation and Transformations. Paris: IRD Éditions.

Horrocks, Mark and Stuart Bedford, 2005. Microfossil analysis of Lapita deposits in Vanuatu reveals introduced Araceae (aroids). Archaeology in Oceania 40: $67-74$.

Kaltal, Martha, Yoko Nojima and Stuart Bedford, 2004. Wokbaot Bakagen wetem Olgeta Blong VCHSS. Saet Sevei mo Akaeoloji. Port Vila: VCHSS, Vanuatu Cultural Centre.

Leavesley, Matthew, Bernard Minol, H. Kop, Vincent Kewibu, 2005. Crosscultural concepts of archaeology. Kastom, community, education and cultural heritage management in Papua New Guinea. Public Archaeology 4: 3-13.

Lightner, Sara and Anna Naupa, 2005. Histri Blong Yumi Long Vanuatu. 3 volumes plus teacher's guide. Port Vila: Vanuatu Cultural Centre.

Mead, Jim I., David W. Steadman, Stuart H. Bedford, Christopher J. Bell and Matthew Spriggs, 2002. New extinct mekosuchine crocodile from Vanuatu, South Pacific. Copeia 3: 632-41.

Regenvanu, Ralph, 1999. Afterword: Vanuatu perspectives on research. Oceania 70: 98-101.

Regenvanu, Ralph, 2005. The changing face of custom. People and Culture in Oceania 20: 37-50. 
Regenvanu, Ralph, Peter Kolmas, Martha Yamsiu, David Roe and Jean-Christophe Galipaud, 1992. Wokabaot Blong Olgeta Blong VCHSS. Port Vila: The Vanuatu Cultural and Historic Sites Survey.

Regenvanu, Ralph and Matthew Spriggs, 1996. Ripot i go long ol man Mangaliliu mo Lelepa long saed blong stadi blong Kaljoral Senta long Arkiologi blong Mangaasi, Okis kasem Septemba 1996. Typescript, on file Vanuatu National Library.

Roe, David, Ralph Regenvanu, Francois Wadra and Nick Araho, 1994. Working with cultural landscapes in Melanesia: some problems and approaches in the formulation of cultural policies. In Culture-Kastom-Tradition. Developing Cultural Policy in Melanesia, ed. L. Lindstrom and G. White, 115-30. Suva: Institute of Pacific Studies, USP.

Roe, David and Jean-Christophe Galipaud, 1994. The Vanuatu Cultural and Historic Sites Survey: Project Description, Evaluation and Recommendations. Final Report. Port Vila: The Vanuatu Cultural and Historic Sites Survey.

Sand, Christophe and Stuart Bedford (eds), 2010. Lapita: Ancêtres océaniens/ Oceanic Ancestors. Paris: Musée du quai Branly/Somogy.

Shing, Richard and Stuart Bedford, 2005. Wanem ia arkioloji. Port Vila: The Vanuatu Cultural Centre.

Shing, Richard, Stuart Bedford, Matthew Spriggs and Ralph Regenvanu, 2005. Ripot long saed blong stadi long arkioloji long Teouma 2004. Typescript, on file Vanuatu National Library.

Shing, Richard, Stuart Bedford, Matthew Spriggs and Ralph Regenvanu, 2007a. Ripot long saed blong stadi long arkioloji long Teouma 2004, 2005, 2006. Typescript, on file Vanuatu National Library.

Shing, Richard, Stuart Bedford, Matthew Spriggs and Ralph Regenvanu, 2007b. Wanem ia arkioloji. Port Vila: The Vanuatu Cultural Centre.

Spriggs, Matthew, 1984. The Lapita Cultural Complex: origins, distribution, contemporaries and successors, Journal of Pacific History 19(4), pp. 202-223.

Spriggs, Matthew, 1996. Report to the Vanuatu Government on archaeological research and training program at Mangaasi on the island of Efate, August to September 1996. Typescript, on file Vanuatu National Library.

Spriggs, Matthew, 1997. The Island Melanesians, Oxford, Blackwell.

Spriggs, Matthew, 1999. Remote delivery of archaeological discovery results to a classroom context. In Archaeology, Communication and Language. No Barriers Seminar Papers, ed. Paul Wallin, vol. 1, 1998: 5-7. Oslo: Kon Tiki Museum. 
Spriggs, Matthew, 2000. The Pacific archaeology teaching project: an experiment in remote delivery of archaeological results to a classroom context. In Essays in Honour of Arne Skjolsvold. Occasional Papers of the Kon-Tiki Museum, ed. P. Wallin and H. Martinsson-Wallin, volume 5, 122-31. Oslo: Kon-Tiki Museum.

Spriggs, Matthew, 2002. Report to the Australia and Pacific Science Foundation on the project 'Investigation of the initial human colonisation of Vanuatu and its later transformations' for 2001. Typescript, on file Vanuatu National Library.

Spriggs, Matthew, 2003. Report to the Pacific Biological Foundation on the project 'Investigation of the initial human colonisation of Vanuatu and its later transformations' for 2002. Typescript, on file Vanuatu National Library.

Spriggs, Matthew, 2004a. Investigation of the initial human colonisation of Vanuatu and its later transformations. Report to the Pacific Biological Foundation for 2003 and Final Report. Typescript, on file Vanuatu National Library.

Spriggs, Matthew, 2004b. Archaeological investigation of the Lapita site of Teouma: The critical missing piece in the study of Central Vanuatu environmental and cultural history. Final Report to the Pacific Biological Foundation. Typescript, on file Vanuatu National Library.

Spriggs, Matthew, 2006. World Heritage values for the Roy Mata-Mangaasi Complex, Northwest Efate, Vanuatu. Report as part of the nomination papers for the proposed World Heritage area, submitted to UNESCO. Typescript, on file Vanuatu National Library.

Spriggs, Matthew, 2007. Research report on NGS grant number 8038-06: Solving the riddle of Pacific Settlement: the archaeology of an Early Lapita cemetery and village site at Teouma, Vanuatu. Typescript, on file Vanuatu National Library.

Spriggs, Matthew and Stuart Bedford, 1999. Summary report to the Vanuatu Government on archaeological research and training program at Mangaasi, West Efate 1997-1999. Typescript, on file Vanuatu National Library.

Spriggs, Matthew and Stuart Bedford, 2001. Arapus: a Lapita site at Mangaasi in central Vanuatu? In The Archaeology of Lapita Dispersal in Oceania: Papers from the Fourth Lapita Conference, June 2000, Canberra, Australia, ed. G.R. Clark, A.J. Anderson and T. Vunidilo, 93-104. Canberra: Pandanus Books. Terra Australis 17.

Tryon, Darrell, 1999. Ni-Vanuatu research and researchers. Oceania 70: 9-15. 
19. Olfala Histri Wea i Stap Andanit long Graon Archaeological Training Workshops in Vanuatu

Valentin, Frédérique, Richard Shing and Matthew Spriggs, 2005. Des Restes Humains Datés du début de la période de Mangaasi (2400-1800 BP) Découverts à Mangaliliu (Efate, Vanuatu). Comptes Rendus Palévol 4: 420-27.

Ward, G., 1990. The Mangaasi pottery and the Mangaasi site. In Saying So Doesn't Make It So, ed. D. Sutton, 153-67. New Zealand Archaeological Association Monograph 17.

Yona, Salkon, 2006. Excerpts from joint presentation with Stuart Bedford at 26 Years Collaboration Conference (Recorded 8/11/06 [Copy held by National Film, Photo and Sound Archives, Vanuatu Cultural Centre]). 